\title{
PENGARUH PERJANJIAN INTERNASIONAL TERHADAP PERUBAHAN-PERUBAHAN KUHP BERKAITAN DENGAN TINDAK PIDANA AERIAL HIJACKING
}

\author{
Oleh: \\ Ruby Hadiati Johny \\ Fakultas Hukum Universitas Jenderal Soedirman Purwokerto
}

\begin{abstract}
International Agreement is very important for growth of national law, especially national criminal law. International Agreement as one of legal source can give information about growth at national law that carried out bilateral conventions and multilateral. The growth of Criminal law in Indonesia is influenced by many growths of international society. This influence is progressively with existence of globalization that affecting at changes of behavior which outwardly shift in law orders. Globalization era have supported by information technology, transportation and communications. One of fast transportation is plane. ICAO as world organization that concern in problem of air transportation said that this transportation is gristle with danger by people with various motifs. Conventions that carried out by ICAO such as Convention of Tokyo year 1963, Convention of Hague year 1970, Convention of Montreal year 1971 that influenced at KUHP after Indonesia have applicator this application can see in Law No. 4 Year 1976 that concerning Hijacking.
\end{abstract}

Kata kunci: Perjanjian Internasional sangat berpengaruh terhadap perubahan hukum pidana khususnya KUHP

\section{A. Pendahuluan}

Hukum pidana internasional sebagai disiplin hukum memiliki dan telah memenuhi 4 (empat) unsur sebagai berikut:

1. Asas hukum pidana internasional

2. Kaidah-kaidah hukum pidana internasional

3. Proses instrument penegak hukum pidana internasional

4. Obyek hukum pidana internasional ${ }^{1}$

Asas hukum pidana internasional dibedakan asas umum yang bersumber pada hukum internasional, antara lain pacta sunt servanda, sedangkan yang khusus berasal dari Grotius yaitu asas andere au punere, yang berarti terhadap palaku tindak pidana internasional dapat dipidana oleh negara tempat locus delicti dalam batas territorial Negara tersebut diserahkan atau di exstradisi kepada Negara yang memiliki yuridiksi untuk mengadili pelaku tersebut.

Romli Atmasasmita, 2003, Penghantar Hukum Pidana Internasional, Bandung: Refika Aditama, hlm. 13
Asas kedua merupakan perkembangan dari asas pertama yang telah disesuaikan dengan pratek penanggulangan tindak pidana internasional yang berasal dari Bassioni yaitu asas audedera au judicare yang berarti setiap Negara berkewajiban menuntut dan mengadili pelaku tindak pidana internasional dan berkewajiban untuk melakukan kerja sama dengan Negara lain di dalam menangkap, menahan dan menuntut mengadili pelaku tindak pidana internasional.

Asas-asas yang lain bersumber pada hukum pidana nasional antara lain legalitas territorial, nasional pasif dan aktif, asas universal asas non retroaktivitas dan nebis in idem. Di antara asas-asas tersebut yang paling penting adalah asas territorial dan perlindungan yang sering menjadi konflik yuridiksi criminal antara Negara yang satu dengan yang lain. $^{2}$

Ibid., hlm. 14 
Kaidah-kaidah hukum pidana internasional meliputi semua ketentuan di dalam konvensi-konvensi internasional tentang kejahatan internasional baik bilateral maupun multilateral. Instrumen penegakan hukum pidana internasional mengenal prosedur penegakan hukum pidana internasional dan institusi penegak hukumnya, misalnya Interpol, mahkamah pidana internasional (ICC).

Obyek hukum pidana internasional adalah tindak pidana internasional yang menurut "The Concept of international Criminal Juridiction Definition and Limitation of The Subject" (1973) menyebutkan sebagai internaiional crimes:

1. Terrorism

2. Slavery

3. The slave trade

4. Traffic in women and children

5. Traffic in narcotic drugs

6. Traffic in pornography

7. Piracy

8. Aerial hijacking

9. Counterfeiting

10. The destruction of submarine. ${ }^{3}$

Kesepuluh jenis kejahatan internasional di atas merupakan kejahatan yang memiliki aspek/unsur internasional (internatioanal element) dan dapat disebut sebagai kejahatan terhadap masyarakat internasional (delicta juris gentium). Selain itu menurut Daatricourt masih menyebut tipe kejahatan lain yang disebut "Crimel against the universal or World Public Order" termasuk di dalamnya adalah crime against peace, crime against humanity dan war crime.

Aerial hijacking adalah salah satu kejahatan internasional yang pada saat terjadi di Indonesia tahun 1972 ketika pesawat MNA dari Surabaya dipaksa terbang oleh seorang penumpang yang bernama Suherman ke Jogyakarta tapi oleh pilot pesawat, Suherman ditembak dan mati. Kejahatan tersebut memberikan motifasi di bidang hukum khususnya hukum pidana nasional, karena apabila pembajaknya hidup harus diadili dengan menggunakan apa dan apabila itu terjadi pada pesawat udara asing lebih rumit lagi karena pada saat itu Indonesia belum mempunyai perangkat hukum yang menyangkut masalah hijacking, di samping itu Indonesia belum mengikuti atau meratifikasi konvensi-konvensi internasional yang membahas aerial hijacking.

Berdasarkan hal tersebut, Penulis ingin mendeskripsikan tentang peran perjanjian internasional terhadap perundang-undangan di Indonesia khususnya terhadap aerial hijacking dan bagaimana pengaruhnya terhadap KUHP.

\section{B. Pembahasan}

Perjanjian internasional sangatlah penting bagi perkembangan hukum nasional khususnya hukum pidana nasional, karena dari perjanjian internasional sebagai salah satu sumber hukum internasional dapat memberikan perkembangan pada hukum nasional melalui konvensi-konvensi yang diselenggarakan baik oleh Negara-negara ataupun melalui organisasi Perserikatan Bangsa-Bangsa.

Hukum pidana nasional tak terlepas juga dari pengaruh globalisasi saat ini terlibat banyaknya konvensi-konvensi internasional yang diselenggarakan oleh PBB/Organisasi internasional. Undang-undang di Indonesia banyak terjadi sebagai akibat dari perjanjian internasional baik bilateral maupun multilateral, beberapa terlihat undang-undang yang terjadi karena tuntutan masyarakat internasional.

Pengaruh globalisasi juga mempercepat perkembangan/dinamika masyarakat yang berpengaruh terhadap perundang-undangannya. Perkembangan masyarakat dunia sebagai pengaruh globalisasi berdampak pada perubahan-perubahan pada perilaku yang ada akhirnya bergeser pada aturannya dan hukumnya. Globalisasi semakin memanifestasikan dengan didukung teknologi informatika, komunikasi, dan transportasi dan salah satu transportasi yang penting adalah pesawat udara. Perkembangan dari masyarakat yang menyeluruh dengan peraturan-peraturan cosmopolitan seperti pendapat dari Immanuel Kant 
"Globalization is development of a universal community with cosmopolitan right. ${ }^{4}$

Alat transportasi dengan menggunakan pesawat udara pun mendapat perhatian dari ICAO sebagai organisasi yang mengatur masalah penerbangan sipil dunia, karena dirasakan transportasi ini rawan dengan bahaya ancaman dari perseorangan ataupun kelompok dengan berbagai motif yang dapat membahayakan penumpang/pesawat udara. ICAO sebagai organisasi yang menangani masalah penerbangan sipil mempunyai perhatian yang sangat besar terutama setelah banyak kasus-kasus peledakan pesawat udara sipil yang memelan banyak korban sehingga ICAO sebagai wadah dari organisasi penerbangan sipil berusaha untuk mengatasinya.

Tindak pidana yang sering dilakukan pada pesawat udara sipil disebut dengan "pembajakan udara" atau aerial hijacking, yang gejalanya dimulai pada tahun 1960. Semula perbuatan tersebut bermotif politik misalnya untuk meminta suaka politik di Negara yang dituju atau memaksa suatu Negara untuk melepaskan kawan seperjuangannya dari tahanan/penghukuman oleh Negara. ${ }^{5}$

ICAO memprakasai pada sidang pleno luar biasa (assembli) pada bulan Juli tahun 1970 dan mengambil resolusi yang berisi pengarahan pada council (badan tetap dalam ICAO juga bertanggung jawab pada Assembli) supaya "legal committee dari ICAO" menyiapan rencana "act on unlawful interference against internasional aviation". Kemudian legal committee mengadakan sidang pleno di London pada tanggal 29 September - 22 Oktober 1970 mengenai pembajakan pesawat udara dan sabotase. Kemudian pada tanggal 1 - 6 Desember 1970 diadakan konferensi internasional tentang Hukum Udara (Conferensi On Air Law) di bawah pengawasan ICAO.

Konferensi itu menghasilkan perjanjian internasional tentang "pemberantasan

Ade Maman Suherman, 2003, Organisasi Internasional dan Integrasi Ekonomi Regional Dalam Perspektif Hukum dan Globalisasi, Jakarta: Ghalia Indonesia, hlm. 35

5 Sudarto, 1981, Kapita Selekta Hukum Pidana, Bandung: Alumni, hlm. 4 penguasaan pesawat udara secara melawan hukum" yang kemudian dikenal dengan konvensi The Haque tahun 1970. Pada konvensi Haque ada beberapa yang menjadi pertimbangan antara lain :

1. Perbuatan menguasai dan mempertahankan penguasaan

2. Secara melawan hukum pesawat udara, barang

3. Melanggar penyelenggaraan dinas penerbangan, dan

4. Merongrong kepercayaan bangsa-bangsa atas keamanan sipil dan perbuatan tersebut sangat mencemaskan.

Pada pasal 1 konvensi The Haque tahun 1970 menyebutkan dengan tegas bahwa orang yang dalam pesawat udara yang ada dalam penerbangan :

1. Secara melawan hukum dengan kekerasan, dengan ancaman kekerasan atau dengan suatu cara intimidasi yang lain, menguasai atau mempertahankan penguasaan pesawat itu, atau melakukan percobaan untuk itu.

2. Membantu seseorang yang melakukan atau mencoba untuk melakukan perbuatan tersebut, melakukan suatu tindakan pidana.

Negara-negara yang bergabung dalam ICAO yang telah mengikatkan diri pada perjanjian itu untuk mengancam pidana yang berat terhadap tindak pidana yang dimaksud pasal 1 konvensi The Haque dan konvensi ini belum sampai membahas mengatur masalah sabotase. Pada tanggal 23 September 1971 diadakan perjanjian Montreal pengaturan Aerial Hijacking lebih luas bukan hanya perbuataan penguasaan pesawat udara membahayakan keselamatan orang dan barang dan juga perbuatan-perbuatan terhadap keselamatan penerbangan sipil pada umumnya.

Pada awalnya ICAO terbentuknya berdasarkan perjanjian Paris pada tanggal 13 Oktober 1919 (Convention relating to the regulation of Aerial Navigation). Setelah konvensi Pari ini pada tahun 1926 mengadakan perjanjian Iberia Amerika kemudian pada tahun 1927 dibentuk perjanjian Pan Amerika dan ketiga perjanjian itu diganti dengan perjanjian Chicago tahun 1944. 
Tujuan dari ICAO adalah mengembangkan asas-asas dan teknik penerbangan internasional dan menunjuk perencanaan dan pengembangan transportasi udara internasional dengan cara antara lain:

1. Menjamin keselamatan dan ketertiban pertumbuhan penerbangan sipil internasional di seluruh dunia

2. Memenuhi kebutuhan rakyat dunia akan penerbangan yang aman, teratur, efisien dan ekonomis.

3. Menambah keselamatan dalam penerbangan internasional (pasal 44 Konvensi Chicago tahun 1944) ${ }^{6}$

Jadi ICAO telah menyelenggarakan tiga perjanjian internasional dalam rangka memberantas/menanggulangi aerial hijacking. Perjanjian itu antara lain :

1. Konvensi Tokyo 1963 tentang tidak pidana dan perbuatan-perbuatan lainnya yang dilakukan dalam pesawat udara (Convention of Offences and Center Other acts Committee on Board air (raft).

2. Konvensi The Haque 1970 (Convention for The Suppression of Unlawful seizure of aircraft) tentang pemberantasan penguasaan pesawat udara secara melawan hukum.

3. Konvensi Montreal tahun 1971 tentang pemberantasan tindakan-tindakan melawan hukum yang mengancam keselamatan penerbangan sipil (convention for Suppression of in lawful acts against the safety of civil aeration). ${ }^{7}$

Suatu perjanjian internasional akan menjadi bagian hukum nasional suatu Negara bila di inkroporasikan dalam suasana hukum nasional suatu Negara. Negara-negara yang ikut menyetujui dan mengikatkan diri pada perjanjian internasional adalah dengan cara sebagai berikut :

1. Penandatanganan (signature)

2. Pengesahan (ratification) ${ }^{8}$

Pada konvensi Wina ditegaskan dalam pasal 12 yaitu:

Ibid, hlm. 5

Ibid, hlm. 6

Baur Mauna, 2003, Hukum Internasional Pengertian dan Fungsi Dalam Era Dinamika Global, Bandung: Alumni, $\mathrm{hlm} .16$
1. Persetujuan Negara untuk diikat suatu perjanjian internasional dapat dinyatakan dalam bentuk tanda tangan wakil Negara tersebut.

2. Bila perjanjian itu sendiri menyatakannya.

3. Bila terbukti bahwa Negara-negara yang ikut berunding memyetujuinya.

4. Bila full power wakil-wakil Negara menyebutkan demikian atau dinyatakan dengan jelas waktu perundingan. ${ }^{9}$

Dalam perjanjian Tokyo, The Haque dan Montreal, Indonesia ikut meratifikasinya dan disahkan pada tanggal 31 Maret 1976 dalam Undang-undang No. 2 Tahun 1976, sedangkan ketiga perjanjian tersebut menjadi Undangundang No. 4 Tahun 1976. Dengan diratifikasinya ketiga perjanjian internasional yang diselenggarakan oleh ICAO maka telah terjadi perubahan dalam KUHP Indonesia.

Perubahan-perubahan itu antara lain:

1. Perubahan dan penambahan Pasal 3 dan Pasal 4 angka 4 dari Kitab Undang-undang Hukum Pidana.

2. Menambah pasal baru dalam Kitab Undangundang Hukum Pidana sesudah 95, ialah Pasal 95a, 95b, dan 95c.

3. Menambah sebuah Bab baru ialah Bab XXIX A Kitab Undang-undang Hukum Pidana, Buku II setelah Bab XXIX. Bab baru ini mengatur kejahatan penerbangan yang terjadi atas 18 Pasal, yaitu Pasal 479 a sampai dengan 479r. Pasal 3 KUHP berbunyi sebagai berikut: "Ketentuan pidana dalam perundang-undangan Indonesia berlaku bagi setiap orang yang di luar wilayah Indonesia melakukan tindak pidana di dalam kendaraan air atau pesawat udara Indonesia."

Pasal 95a berbunyi sebagai berikut:

1. Yang dimaksud pesawat udara Indonesia adalah pesawat udara yang didaftarkan di Indonesia.

2. Termasuk pesawat udara Indonesia adalah pesawat udara asing yang disewa tanpa awak pesawat dioperasikan oleh perusahaan penerbangan Indonesia.

Pasal 4 ke 4 Perubahannya sebagai berikut:

Ibid., hlm. 116-117 
Salah satu kejahatan yang tersebut dalam Pasal-Pasal 438, 444 sampai dengan Pasal 446 tentang pembajakan laut dan Pasal 447 tentang Penyerahan kendaraan air kepada kekuasaan bajak laut dan Pasal 479 huruf $j$ tentang penguasaan pesawat udara secara melawan hukum, Pasal 479 $1 \mathrm{~m} \mathrm{n}$ dan o tentang kejahatan yang mengancam keselamatan penerbangan sipil.

Jadi penambahan Pasal 4 ke 4 ini adalah Pasal 479j, 491- 479o Asas-asas ini tidak hanya melindungi kepentingan negara Indonesia saja, tetapi juga kepentingan internasional oleh karena itu asas ini juga disebut asas penyelenggaraan ketertiban dunia.

Pengertian tentang pembajakan pesawat sendiri terdapat dalam Pasal 479j, sebagai berikut :

Barang siapa dalam pesawat udara dengan kekerasan atau ancaman dalam bentuk lainya, merampas atau mempertahankan rampasan atau menguasai pengendalian pesawat udara dalam penerbangan, dipidana dengan pidana penjara selama-lamanya lima belas tahun.

Dengan perjanjian internasional yang diratifikasi oleh Indonesia membawa pengaruh pada KUHP, khususnya dalam tindak pidana aerial hijacking yaitu terdapat perubahan dalam bentuk KUHP yaitu menambah Pasal baru 95a, b, c, dan baru yaitu Bab baru yaitu Bab XXIX dari Pasal 479a, - Pasal 479b.

\section{Penutup}

1. Simpulan

a. ICAO sebagai organisasi wadah dari penerbangan sipil dunia telah menyeleng- garakan tiga perjanjian internasional, yaitu Konvensi Tokyo 1963, Konvensi The Haque 1970, dan Konvensi Montreal 1971 sebagai bentuk usaha untuk memberantas aerial hijacking.

b. Indonesia ikut meratifikasi ketiga perjanjian internasional tersebut menjadi Undang-undang Nomor 4 Tahun 1976 dengan demikian ketiga perjanjian internasional membawa perubahan-perubahan pada KUHP yaitu menambah Pasal 95a, b,c dan bab baru yaitu XXIX A.

\section{Rekomendasi}

Agar supaya Negara Indonesia menjadi negara yang maju dan tidak ketinggalan di era globalisasi ini, Indonesia harus mengikuti perkembangan masyarakat internasional yaitu dengan mengikuti perjanjian-perjanjian internasional baik yang bilateral maupun multilateral yang nantinya akan berpengaruh pada pembentukan hukum nasional yang berwawasan internasional.

\section{Daftar Pustaka}

Atmasasmita, Romli. 2003. Penghantar Hukum Pidana Internasional. Bandung: Refika Aditama;

Mauna, Baur. 2003. Hukum Internasional Pengertian dan Fungsi Dalam Era Dinamika Global. Bandung: Alumni;

Suherman, Ade Maman. 2003. Organisasi Internasional dan Integrasi Ekonomi Regional Dalam Perspektif Hukum dan Globalisasi. Jakarta: Ghalia Indonesia;

Sudarto. 1981. Kapita Selekta Hukum Pidana. Bandung: Alumni. 